\title{
ELITE AND LEADERSHIP CHANGE IN LIBERAL DEMOCRACIES
}

\author{
John Higley \& Jan Pakulski
}

Starting with the ascendancies of Margaret Thatcher, Ronald Reagan, and Helmut Kohl in the 1980 s, there has been a perceptible shift in the character and style of political leadership in liberal democracies. This is the rise of leaders less inclined to engage in a politics of compromise and consensus and more disposed toward peremptory actions backed by force or its threat. These leaders gain executive office through steadily more plebiscitary electoral contests in which their ostensibly superior instincts are glorified and their competitors' alleged defects are savaged. In office, they concentrate government power in core executives at the expense of legislatures and bureaucracies, and they wield power with greater impunity than predecessors. The shift is not uniform across all liberal democracies, and in the countries where it is most noticeable it has not been linear - there are ebbs and flows. But a trend toward more determined and resolute leaders - or, at least, leaders widely perceived as such is evident: George W. Bush and Tony Blair; Junichiro Koizumi and Silvio Berlusconi; Australia's John Howard and Denmark's Anders Fogh Rasmussen. José Zapatero in Spain, Stephen Harper in Canada, and Angela Merkel in Germany may prove to be further illustrations, while the aspirations of forceful individuals to national leadership elsewhere should not be ignored - Nicolas Sarkozy and Jean-Marie Le Pen in France, Carl I. Hagen in Norway, for a time Jörg Haider in Austria, Pim Fortuyn in the Netherlands before his assassination. Although the label may be overly dramatic, 'Ceasarist' leaders who gain power by plebiscitary means form a trend somewhat reminiscent of European politics during the interwar decades (cf. Linz 1978; Linz and Stepan 1978; Lukacs 2005; Paxton 2004).

This apparent shift in the character and style of political leaders is not the full story. In complex liberal democracies leaders are embedded in, and their effectiveness significantly depends upon, political elites: tiny groups of strategic position-holders with the organized capacity to affect political outcomes regularly and substantially (Higley and Burton 2006: 58). Leaders with forceful images are in important degree creations of elites - horses they ride to power. The image of Ronald Reagan as a decisive leader was initially the handiwork of a public relations firm in California, and from start to finish his presidential leadership was carefully choreographed and staged by power-holders who knew much more about politics and issues of the day than Reagan ever bothered to learn (Cannon, 1982). This is transparently the case with the unworldly George W. Bush, who, possessing a household name, has been the puppet of a neo-conservative elite that plucked him from the politically innocuous Texas governorship in order to bull itself into executive power (Lind, 2003). In some situations a leader's aura of strength may stem primarily from disarray among an opposing elite. Margaret Thatcher, who never won a majority of votes, owed much of her leadership image to chaos in the Labour Party elite, just as Tony Blair's image has owed not a little to the Tory elite's wanderings in the political wilderness.

The ways in which leaders and elites affect each other is, of course, a knotty problem in political analysis. Few would deny that their relations are reciprocal: leaders galvanize and orient elites, but without the power and influence that elites possess leaders can accomplish little. It is also obvious that relations between leaders and elites display much variation. Like Reagan and Bush, some leaders appear to be not much more than front men for well-formed 
elite groups. But like Tony Blair and John Howard, other leaders impose their wills on the elites they head. Everywhere, leaders act within the norms and structures of elite politics, some of which allow leaders wide latitude while others tightly constrain them. At present in the U.S., for example, a considerable part of the political elite is threatening to punish George W. Bush and his White House mandarins and cabinet secretaries for breaching norms about the scope of presidential power and the degree to which it can be exercised unilaterally. Beyond loose or tight norms, leaders must contend with elite structures that may be quite concentrated or fragmented. A fair amount of research shows that in liberal democracies elite structures consist of extended circles and networks of political influence and personal acquaintance that tie together several thousand of the uppermost figures in politics, government administration, business, trade unions, the media, a bevy of interest groups, and so on. Such complex and far-flung elite webworks usually stifle a leader's single-minded pursuit of his or her political aims.

These considerations suggest that if a shift toward more forceful leaders is occurring in at least some liberal democracies then a comparable shift in elites must also be occurring. We intend to explore the thesis that this is a time of increasingly forceful leaders embedded in more aggressive, tightly organized, and mutually antagonistic elites in at least some liberal democracies. We conduct this exploration from the standpoints of Vilfredo Pareto and Max Weber. Specifically, we combine Pareto's discussion of how fox-like elites governing 'demagogic plutocracies' give way to leonine elites and more forceful rule (1935: esp. paras. $2178,2190,2221-29,2231-36,2257,2480)$ with Weber's discussion of how 'leader democracy' (Führerdemokratie) needs charismatic leaders to be sustainable (1978: 1121-7, 1458-60). Given the philosophical differences between Pareto and Weber, combining their insights may seem problematic, although it has been argued that the two theorists, who were contemporaries, engaged in an 'unacknowledged dialogue' (Sica, 1988: 225-49). Both viewed politics from an elite and leadership perspective; they observed and diagnosed the same political trends in Europe (and to a lesser extent the U.S.) during the stormy early years of the twentieth century; they held unsentimental views of democracy and regarded effective elites (Pareto) and charismatic leaders (Weber) as crucial for its workings. In spite of different philosophical underpinnings - Pareto's positivism and Weber's neo-Kantianism their political analyses were complementary. Pareto saw individual leaders as displaying all manner of foibles and stupidities, so he thought it more profitable to concentrate on the overall psycho-social physiognomies and dispositions of elites. Weber, as his concept of 'leader democracy' implies, regarded charismatic and statesmen-like leaders as vital, and he paid little attention to the characteristics of elites as wholes. Pareto largely ignored the socialhistorical and institutional contexts in which elites act, while Weber paid close attention to such contexts. When combined, however, the visions of Pareto and Weber dissect the vertical aspects of democracies. Pareto attacked the shortcomings and failures of their elites; Weber worried about the quality of their leaders in the era of parliamentary and mass party politics; both outlined elite and leadership changes that would or should occur.

These visions are a springboard from which to examine elite and leadership changes that appear to be impelled by extraordinary conditions during the past twenty-five years. Principally and in a nutshell, these conditions are the Soviet Union's collapse and the globalisation it spurred; recent threats to security posed by terrorism; and the massive numbers of migrants fleeing failed or failing non-Western states. First, the Soviet Union's collapse spurred an almost universal embrace of three principles: the worth of private and deregulated capitalist markets; the superiority of popularly elected governments; the necessity for liberty in the form of an unrestricted circulation of information. But the whole-hearted 
embrace of these principles has tended to disorient elites and leaders in liberal democracies, causing them to adopt unrealistic expectations about what can be accomplished in domestic and international politics. Second, the spectre of terrorism encourages more assertive and zero-sum political competitions, especially in the domain of national security. Widely publicized terrorist threats, accompanied by portrayals of the US-led interventions in Iraq and Afghanistan as part of a life-or-death 'global war against terror,' are used by aggressive elites and forceful leaders to rally popular support, devastate political competitors, and justify large expansions of executive power as necessary to counter external and internal enemies. Third, migrations of millions of people from failed or failing non-Western states are increasingly viewed as undermining the social and political integration of the liberal democracies to which the migrants flee. Technologies for instant worldwide communication and rapid transportation - also key aspects of globalisation - facilitate trans-national identities among migrants that make their allegiances to host countries uncertain. Migrant communities perceived as semi-allegiant or even non-allegiant ignite host population support for rising elites and leaders who promise illiberal crackdowns on these communities, the sealing of national borders against illegal migrants, and greatly reduced immigration intakes.

These three conditions exert powerful centripetal pressures on the politics of liberal democracies. Our enumeration is hardly exhaustive. The spectres of disease pandemics and global warming, the volatility of petroleum and other commodity markets, as well as a host of employment insecurities and the economic consequences of ageing populations can readily be added. Our claim is simply that centripetal pressures stemming primarily from the conditions we have mentioned are a root cause of the changing elite and leader patterns in which we are interested. They intensify discords in liberal democratic politics, promote executive power concentrations, and favour putatively leonine elites and forceful leaders. One of Pareto's dicta is pertinent: 'When centripetal forces are dominant, the central government will be called on to provide it. Whenever circumstances turn in favour of this centripetal phase, a pre-existing central government, or a central authority new both in form and substance, asserts itself sooner or later' (1921/1984: 47).

\section{Elites and leaders}

It is well known that Pareto and Weber saw rule by elites-cum-oligarchies as inescapable in all societies, regardless of the form governance takes. Pareto famously claimed that 'Everywhere there exists a governing class... Whether universal suffrage prevails or not, always it is an oligarchy that governs' (1935: para. 2183). Weber just as famously wrote that 'Everywhere the principle of the small number - that is, the superior political manoeuvrability of small leading groups - determines political activity. In mass states, this Caesarist element is ineradicable' (1978: 1414). Both believed, nonetheless, that different elite and leader modes are associated with different kinds of political regimes. Pareto depicted ruling elites in 'demagogic plutocracies' - his pejorative term for parliamentary democracies - as consisting of a far-flung alliance of fox-like politicians and profit-seeking 'speculators' who, through innumerable deals and deceptions, prevent an alliance of more leonine politicians and 'rentiers' from governing. Parliaments, Pareto held, are the arenas in which the dominant fox-speculator alliance arranges the chicaneries necessary to keep itself in power. Similarly, Weber portrayed the early Weimar democracy and most other democracies of his time as essentially 'leaderless,' with members of elected parliaments engaged in a chaotic horse-trading of sectoral interests. 
Neither man thought that the situation he described could persist indefinitely. Pareto believed that the despoilments by which the fox-speculator alliance keeps itself in power ultimately undermine the economy and the state's fiscal viability, opening the door to a takeover by the opposing lion-rentier alliance (1921/1984: 71; see also Femia 2001; 80-81). However, the latter's dominance eventually proves so excessively coercive and tight-fisted that it provokes a new crisis propitious for the fox-speculator alliance's return to power. And so modern history proceeds, in endless cycles of alternating fox-like and lion-like elite rule. Weber was not quite so pessimistic or resigned. He searched for a way by which 'mass democracy' could be saved from itself. Holding that any such democracy is necessarily a 'leader democracy' (Körösényi 2005), he theorized that rule by professional politicians who live 'off' politics, always feathering their own nests, might be transcended in 'unusual situations' by charismatic leaders not beholden to narrow sectoral interests and possessing a keen concern for the national good. If directly elected rather than chosen by parliaments, such leaders, living 'for' rather than 'off' politics, would use their charisma and 'demagogy' to create powerful mass followings and loyalties that would enable them to pursue national interests and goals. The result would be a 'plebiscitary' or 'leadership' democracy, which Weber regarded as mass democracy’s only sustainable form (Beetham 1984: 264-67).

The foregoing is, of course, a pastiche of the complex and subtle analyses made by Pareto and Weber. But their analyses are sufficiently familiar to most students of elites and leadership to make another exegesis unnecessary (see, inter alia, Finer 1965, 1968; Parry 1969/2006; Parkin 1982; Beetham 1974/1985; Femia 2001). A few elaborations will, however, be useful. First, Pareto's metaphorical distinction between elites as 'foxes' and 'lions' is at odds with any typology based on elites' declared ideological commitments. Pareto dismissed ideologies as 'derivations' - rationalizations-cum-rhetorical devices - and instead anchored his distinction in allegedly deeper and more basic psychological predispositions ('residues') that shape elites' modes of rule. Lions, manifesting the residues of 'group-persistence,' are tough, stubborn, and aggressive; they do not hesitate to use violence to achieve and hold on to power, typically framing and merchandizing their actions in terms of mass ethno-nationalist and religious loyalties. Foxes are cunning, clever, and astute; they use wit, manipulation, and diplomacy, rather than force, and frame and merchandize their exercise of power in terms of economic prosperity and their ostensible representation of diverse public interests. Unlike ideological leanings - which elites often alter - these predispositions and proclivities remain constant. So do accompanying leadership styles. Foxes never roar; they always behave in guileful and stealthy ways. Lions never shed their manes and grow bushy tails; force and fear are their preference.

For Pareto, as we have noted, elite circulation always takes a cyclical form: foxes displace lions and new lions then displace the foxes (1935:2221-2229ff.; 1921/1984:47). In the one cycle, centrifugal conditions de-centralize power, and this favours opportunistic and cunning elites adept at combining dispersed pieces of power in order to ascend and rule. In the other cycle, centripetal pressures force power's re-centralization, and this favours aggressive and forceful elites adept at wielding it more unilaterally. Each cycle inevitably comes to an end because each elite type is prone to characteristic dysfunctions that produce unsustainable 'disequilibria'. Lions fail because they exaggerate the effectiveness of force, and when they overstretch its use they are out-manoeuvred by foxes. But foxes become soft and indecisive ('humanistic'), enabling lions waiting in the wings to exploit these weaknesses. The mode of this circulation varies in depth and violence between societies and within them over time. In general, lions tend to displace foxes and impose themselves through sharp power takeovers; foxes take power through gradual penetration and permeation 
of a lion-dominated governmental arena. If lions enter that arena from outside it, their seizure of power takes a revolutionary form; if they displace foxes from within the arena via factional politics, their takeover is less abrupt.

This embryonic theory of elite circulation (implied rather than stated in detail by Pareto) resembles a path-dependency account of political change. Pareto seems to suggest that each elite cycle is brought about by the preceding cycle's accumulating ills (disequilibria), which flow from the distinctive weaknesses of whichever type of elite is then ascendant. The failures of cunning foxes in their Machiavellian excesses of deception and stealth open the way to blunt lions and their Hobbesian excesses of coercion and force. This cyclical circulation is shaped not only by the elites' qualitative deterioration, but also by sharply asymmetric sentiments (residues) between the governing elite and the masses - in which case the circulation tends to be revolutionary - or by a less dramatic asymmetry of sentiments within the elite stratum itself - in which case circulation is likely to be more peaceful. The elite cycles also tend to coincide with economic and cultural oscillations: the predominance of lions and their rentier allies accompanies periods of economic decline involving revivals of nationalism and religiosity; the ascendancy of foxes and speculators accompanies periods of economic prosperity and secularism. This is more an elite "pathdependency' sequence than a 'circumstances/conditions' construct (Timasheff 1965:68; Parry 1969/2006: 57-63).

Pareto's elite types never appear in pure form and never operate in isolation from each other. The predominance of each is always a matter of degree. Behind every leonine elite in power there is always a foxy one waiting for the lions' dysfunctions and errors to create a political opening, and vice versa. Because such dysfunctions and errors are inevitable, neither lions nor foxes are inherently superior. When ascendant each degenerates, which is why, in Pareto's view, elite rule seldom stabilizes for any long period of time. ${ }^{1}$ History is not only the graveyard of elites replacing each other, it is also the stage on which oscillations and stylistic successions are played out without end. This cyclical and cynical (but realistic?) view of history formed a powerful counter-vision to optimistic liberaldemocratic scenarios of progress, and it was, of course, a fundamental retort to Marxism.

Although Weber expounded his concept of 'leader democracy' and his hoped-for alternative of a more charismatic and plebiscitary 'leadership democracy' in a fragmentary way, his analysis helps us to understand the socio-historical and institutional contexts in which changes in leaders occur. According to Weber, charismatic leadership 'always results from unusual, especially political or economic, situations' (1978: 1121). These are situations of crisis or of sudden and unexpected developments that trigger collective excitements, anxieties, and expectations culminating in 'surrender to heroism' (1978: 1132). The situations or developments are transitional and are followed by more stable forms of authority, but so

\footnotetext{
${ }^{1}$ Pareto and his intellectual comrades Mosca and Michels stressed the overriding and very personal interests of elites in obtaining power's immediate psychological rewards and social protections. In pursuing power, elites of a similar type support each other, and this mutual support - reflecting calculated power interests more than ideological affinities - enhances their success. Put differently, the preponderant interest of elites is in wielding power, not in promoting the interests of a collectivity such as a class or an ethnie, or realizing an ideological program. Elites that disregard or downplay the vicissitudes of power and its exercise fall victim to more ruthless or cunning competitors.
} 
long as they last the transitions are tension-filled. Charismatic and plebiscitary leadership emerges as 'the most important transitional type' of authority (1978:267) - a sort of halfway house between charismatic domination and the legal-rational form stable political institutions must ultimately take in modern societies. Under condition of mass democratisation - in particular, the direct election of political leaders by masses of voters - charismatic and plebiscitary leadership may emerge and rest on popular acclamation (elections) and public trust. Leaders will act 'on behalf of the people' and legitimate their decisions in terms of the 'will of the people'. This 'will of the people' is evoked and cultivated through leaders' direct appeals and their use of demagogy (1978: 241-71, 1111-1155).

Charismatic and plebiscitary leadership, Weber observes, extends to a leader's administrative staff - what might also be thought of as the elite surrounding the leader. Staff members worship the leader (the charismatic principle) and bask in the confidence the masses have in him or her (the plebiscitary principle). This staff elite - typically the leader's trusted confidants - cannot easily be integrated into a hierarchical authority structure because the foundations of its power rest outside the institutional realm. Therefore, instead of an integrated hierarchy charismatic and plebiscitary leadership tends to produce centralized and autocephalous spheres of authority and diluted staff elite competencies. In this situation, top figures in the elite exercising executive power cannot be controlled by parties or parliaments and cannot be dismissed without the leader's approval. Their political fate is determined by the leader's trust in them and the 'confidence of the people,' rather than by their administrative competence.

In Weber's view, by paving the way for persons skilled in demagogy, rather than just gifted orators like lawyers, the plebiscitary principle favours 'the type of individual who is most spectacular, who promises the most, or who employs the most effective propaganda measures in the competition for leadership' (1978: 1451). Under plebiscitary leadership, then, politics display the emotional and irrational features typical of charismatically-led orders, and they militate against deliberative policy-making and long-term rationalization. However, charismatic and plebiscitary leadership does not preclude further transition to a more rationalized, orderly, and workable 'leader democracy'. Whether this further transition occurs, as well as its speed, depend on adopting a functional division of powers and forming a strong party machine that takes over as the locus of political allegiance and mobilization of public (electoral) support.

In a well-functioning leader democracy, according to Weber, and as András Körösényi (2005) ably elucidates, a charismatic and plebiscitary leader can be insulated from immediate public pressures and subjected to some collegial control. The leader and the staff elite surrounding him or her still impose themselves on the people, but their political success depends on winning competitive elections - on proving themselves effective in generating mass support. This support is at once diffuse and personalized. Political rivals use rhetoric and image manipulation to engineer personal support, inspire personal loyalty, sway public opinion, and generate trust, especially at the crucial moments of electoral contests. Public support is, in other words, the product of the political process, not of some bottom-up aggregation of pre-existing interests and views (Körösényi 2005: 365). If successful in using rhetoric and image to generate support, a charismatic and statesman-like leader secures public trust, loyalty, and respect. The mass demand for leadership is satisfied, the confidence of the masses is won, and, most important, an aura of responsibility is created and sustained. This, in turn, enables leaders to work with parliamentary colleagues and pursue 'continuous and consistent policies' (Weber 1978: 1459). 
Pareto and Weber were close observers of politics in their respective countries, Italy and Germany, and of European developments more widely, during the twentieth century's early years. Agonizing over Italy's post-World War I political turmoil, which culminated in the 'March on Rome' by Mussolini and his Blackshirts in 1922, Pareto identified the ascending fascists with lions. Initially, he pinned on them his hopes for Italy's renewal, although he recognized that the fascists were ultra-nationalists coming from outside the governmental arena and therefore likely to take power in a revolutionary and violent manner; they were profiting ruthlessly from conditions of social, economic and political crisis, and their repressions of opponents were ugly to behold. In relatively short order (albeit after Pareto's death in 1923), Mussolini and his elite assumed dictatorial power, displaying much aggressiveness, corruption, and brutality, the early signs of which Pareto condemned in a political testament written from his deathbed. Weber, observing only briefly before his death in mid-1920 the already devastating consequences of the Treaty of Versailles for Germany, believed that his country's authoritarian heritage, political extremism, now leaderless bureaucracy, and dispirited masses pointed toward 'a polar night of icy darkness and hardness' unless a charismatic and appropriately demagogic leader emerged and headed off this fate (quoted by Antonio 1995: 2370-71). As things turned out, of course, it was Hitler who emerged as Führer, mimicking Mussolini's title of Duce. The ascendancies of the two leaders and elites induced a proto-leonine shift in ruling styles throughout Europe and parts of the western hemisphere, which even an echo in far-off Australia in the form of an incipient fascist movement, the New Guard (Linz 1978; Paxton 2004; Macintyre 2004: 182).

We encapsulate this familiar history in order to observe that the belligerence and brutality of the fascists/Nazis discredited, so to speak, the image of leonine elites and charismatic leaders. Following their rules by terror, wartime atrocities, and the racism and ultra-nationalism they spouted, the leonine fascists/Nazis were regarded with contempt and hatred. Their grievous over-reaching and consequent defeat in World War II were the start of a shift in elite and leader types ascendant in post-war liberal democracies.

\section{Elites and leaders after World War II}

Pareto and Weber lived in countries and at a time when elite conflicts and rivalries between leaders were - and had always been - largely unchecked. Following national unification in Italy and Germany, deep ideological chasms and mutual distrusts separated opposing elite camps. They disagreed fundamentally about the political institutions on which their new national states rested and they strove to defend or destroy governments of the day according to their conflicting stances and bases of support. The elites that Pareto and Weber knew best were, in a word, deeply disunited. In Italy, to be sure, right-wing monarchical and left-wing republican elite camps fused in the famous trasformismo of 1876, but this proved too narrow to accommodate spreading popular mobilizations of peasants and workers suffering the harshness of industrialization and led by emerging Catholic and socialist elites who had no place in the fused elite and thus no stake in the regime (Cotta 1992). Exacerbated by foreign misadventures such as the Libyan War in 1912, the elite power struggles became steadily more explosive during the years before and after World War I, and they led to fascist dictatorship after the assassination of Socialist leader Giacomo Matteotti in June 1924 and the withdrawal of Socialist deputies from Parliament. In the German Reich authoritarian rule by Bismarck and his successors and by elites associated with them kept the lid on a boiling political pot. But the Imperial regime was reviled by elites leading bourgeois and working- 
class organizations and movements, and the lid finally came off in the 'leaderless' Weimar Republic, the inception of which Weber witnessed.

The disunited condition of Italian and German elites was mirrored in nearly all other European countries (and in all countries of Latin America) before and after World War I. The exceptions were Britain, the Netherlands, Sweden, and Switzerland where, in much earlier and highly contingent circumstances, basic 'consensual' unifications of previously disunited elites had occurred - England's 'Glorious Revolution' in 1688-89; elites in the Dutch Provinces banding together to free themselves from Spanish colonial rule in the late sixteenth century; Sweden's constitutional revolution in 1809; the unification effected by elites in the aftermath of Switzerland's short civil war during 1847-48. Politically, those four countries, with stable liberal oligarchies governing them, constituted marked deviations in a European landscape suffused by unbridged elite divisions and unstable, mainly authoritarian, regimes (Higley and Burton 2006: 33-54). Pareto and Weber thus drew their lessons primarily from a particular pattern of elite relations - disunited - and from the capricious leaders and regimes to which it gives rise.

It is interesting to speculate about how their analyses might have been tempered if Pareto and Weber had had greater knowledge of the consensually united elite pattern. In it extensive communication and influence networks integrate competing factions and leaders who share an underlying consensus about most norms of political conduct and the worth of most existing political institutions. Elite factions and leaders accord each other significant trust, cooperate tacitly to contain explosive conflicts, and compete for political power in comparatively restrained ways. Power sharing is the hallmark of a consensually united elite, and the periodic, peaceful alternations in executive power that mark liberal democracies are its principal manifestation (Higley and Burton 2006: 8-15). Pareto's grudging admiration for the politics practiced by Swiss elites and Weber's praise for William Gladstone's leadership role in British politics suggested an awareness that elites are not always and everywhere as blinkered as Pareto found them in Italy, and that 'leader democracies' are not always as bereft of capable leaders as Weber observed of Germany.

In ways and for reasons too varied to recount here, between about 1950 and 1980 consensually united elites and the liberal democracies they make possible formed in all West European countries where elites had long been disunited (for accounts, see Higley and Burton 2006). Political practices by fox-like elites and relatively prosaic leaders came to prevail. Tripartite deals were cut by government, business, and trade union elites to create neocorporatist condominiums (Schmitter, 1974), and state power was used as a regulatorywelfare tool to expand social rights, a practice that was endorsed, more tacitly than explicitly, by all main elite camps. Elites and leaders of nearly all stripes professed to believe that with minor exceptions the activities of each social grouping contributed to the well being of all groupings. Accordingly, each had an interest in securing the cooperation of others in the common operation of social and political institutions. This sense of social interests meshing in some broad common interest and leaving special interests so limited as to be easily negotiable was widespread among elites and leaders, so much so that it became fashionable to talk about ideology having 'ended'. A period of Tweedledum and Tweedledee political contests undergirded by economic expansion unfolded - the 'halcyon years' that lasted until the oil shocks and stagflation of the late 1970s (Field and Higley 1986). Had he witnessed this, Pareto would have thought his analysis of demagogic plutocracy born out, but Weber might have had second thoughts about the sustainability of democracies with leaders lacking charisma when observing West Germany under Adenauer, Erhard and their chancellor 
successors; Italy in the time of Fanfani, Moro, and the raft of manipulators who followed them; Norway and Sweden under somnolent father figures like Gerhardsen and Erlander; a U.K. led by the uninspiring but devious Macmillan and Wilson; the U.S. during the grey Eisenhower and crafty Johnson and Nixon presidencies; the game of musical chairs being played in Japan by interchangeable LDP leaders - the list could be much longer. On the other hand, Weber might have found his analysis of leader democracy strikingly illustrated by the charismatic Charles de Gaulle's rescue of France from its leaderless Fourth Republic.

Building consensus through deals among major sectors, quieting the less well-off with welfare subsidies, paying off other disgruntled groups, and managing public opinion through increasingly powerful mass media triumphed to such an extent during the twentieth century's third quarter that these practices came to be seen as the natural, or at least normal, form of politics in liberal democracies. In those years hardly anyone wondered if the combination of modern organization and advancing technology might be creating a social order in which it would be difficult to keep a reasonable proportion of the population engaged in activities that others could accept as contributing to the common benefit (but cf. Field and Higley 1980). Starting in the late 1970s, however, the practices of fox-like elites and sly if largely grey leaders were gradually undermined by problems or 'disequilibria' as Pareto would say: the inability of welfare policies to stanch the growth of an impoverished and socially disorganized underclass; structural unemployment impervious to economic growth; high rates of inflation induced by the deficit-financed Vietnam War and OPEC oil shocks; declining state fiscal and regulatory capacities; a proliferation of single-issue parties and volatile voters contributing to the collapse of some of the elite coalitions cemented in neo-corporatist pacts.

These problems-cum-disequilibria were highly publicized in the media and in critical analyses questioning the effectiveness, even the legitimacy, of ascendant leaders and elites in particular, Jimmy Carter and his administration, the premiership of 'Sunny Jim' Callaghan in the U.K., Helmut Schmidt's chancellorship in West Germany. A backlash gathered force and champions of tougher practices captured public support. Economic rationalist and neolaissez-faire principles that leave people to sink or swim on their own became fashionable guides to policy, and previously marginal elite factions and leaders espousing those principles came to the fore. Thatcher, Reagan, and Kohl signified the first wave of more tough-minded governance. Thatcher launched a bold military expedition against Argentina in the Falkland Islands and faced down the previously invincible mineworkers' union. The elite around Reagan did the same to a union of air traffic controllers, undertook a massive military buildup, armed and bankrolled mujhaddin insurgents against the Soviet occupation of Afghanistan and anti-Sandinist 'freedom fighters' in Nicaragua, and voiced unremitting hostility toward the Soviet Union's 'evil empire'. Kohl acted decisively to reunify Germany, he led the EU's Maastricht Treaty effort, his government precipitously legitimated Yugoslavia's break-up, and it unshackled German military forces for previously forbidden foreign deployments.

Because the collapse of Soviet communism between 1989-1991 could plausibly be portrayed, whatever the reality, as a Reagan-Thatcher-Kohl victory, it enhanced the shift toward more forceful elites and leaders. In the U.S. demands for tough market rationalism and 'getting government off people's backs' became drumbeats that in 1994 delivered control of Congress to Republicans under the self-proclaimed 'revolutionary' leadership of Newt Gingrich. The alleged folly of decreased US military spending in the wake of the Soviet collapse became the rallying cry of an aggressive neo-conservative elite that was now fully formed (e.g., Kristol and Kagan, 2000). This elite's no-holds-barred tactics were soon evident in the Clinton impeachment proceedings. When the elite, astride George W. Bush, failed to 
win the 2000 presidential election outright, it ruthlessly exploited an electoral standoff in Florida to obtain the White House keys from a friendly Supreme Court majority. Donald Rumsfeld and other top members of the elite immediately began talking, albeit in secret, about the need to eliminate the Saddam Hussein regime in Iraq (Suskind, 2004: 80-82); the Vice President, Dick Cheney, quietly concentrated executive power in his office beyond any US historical precedent; and a symbiosis of the elite's congressional leaders and Washington 'K Street' business lobbyists began a thorough de-regulation of the energy, communications, financial, and other main economic sectors. In the course of 2001, especially after $9 / 11$, it dawned on observers of American politics that an uncompromising elite had taken over. Coinciding with this US change, Junichiro Koizumi was installed as Japan's prime minister that April; in May Silvio Berlusconi swept into power in Rome; Tony Blair won a second term, nearly by acclamation, a month later; and in November John Howard played the fear cards of asylum-seeking migrant hordes and terrorism to win a third and crushing election victory in Australia.

\section{Current elites and leaders assessed}

Elite alignments and alliances during these early years of the new century are much more complex than during the twentieth century's 'halcyon' period. They involve international elite cartels - economic, political, military, and intelligence - whose national components support each other's positions and policies. Elite positioning in these cartels is as important as positioning in the various national power games. Leaders of the cartels' national components consult frequently with each other, borrow freely from each other's policy repertoires, and shore each other up in crises and election campaigns. Non-stop electronic media promote political competitions that are much more stylistic than substantive. Appeals for support focus on personalities and leadership images rather than policy platforms, and they aim at gaining short-term public approval instead of long-term support. But because these changes have occurred gradually, taking place largely within the elite stratum, they are difficult to assess.

More leonine elites and forceful leaders are, nonetheless, evident in some of the most important liberal democracies. Exhibit $\mathrm{A}$ is the assertion of America's geo-political hegemony by the Bush elite. With its inner core of force-oriented 'Vulcans,' its Spartan élan, executive power concentration, and peremptory actions, the elite has clear leonine features (Mann, 2004; Higley, 2006). Efforts by ruling elites and leaders in Japan and several European countries to ameliorate economic stagnation and unemployment are also more aggressive and forceful. In Japan, for example, Koizumi and his associates have ended fifteen years of deflation, stoked nationalism and military strength, and broken the hold that the "iron triangle' of bureaucrats, businessmen, and LDP placemen long had on economic policy. Merkel in Germany and de Villepin and his shadow, Sarkozy, in France seek to act in tough ways to dispel high unemployment, especially among young people. Nearly everywhere in the face of post-9/11 security fears, governing elites deploy expanded intelligence-security apparatuses to put mass publics, notably immigrant Muslim communities, under close surveillance. Consider, for example, the Bush administration's secret and warrantless monitoring of phone calls and e-mails among what is guessed to be 45 million US residents, as well as its secret inspection of international transfers of bank funds by many residents. Or consider the Blair government's elaborate monitoring and tracking of two score UK residents intent on blowing up airplanes bound for the U.S. in August 2006. Add to these examples the 
complicity of European governments in the CIA's secret transport of abducted terrorist suspects through airports and air spaces in order to imprison or 'rendition' them.

A leonine ascendancy is apparent in other respects. Acting forcefully against long Labour Party proclivities, Tony Blair and his entourage have given the UK core executive expanded resources and a streamlined capacity to impose policies (Burch and Holliday, 200405), traded peerages and honours for campaign contributions, and provided business firms with lucrative opportunities to invest in the public sector. Like members of the Bush elite, most of those in the core executive elite around Blair have not served party and parliamentary apprenticeships but have instead parachuted into power positions from think tanks, public relations firms, business, and other locations. Blair and his lieutenants took the grave step of participating in the invasion of Iraq despite two cabinet resignations and vociferous opposition in parliament, the Labour Party, and the British public. In Australia John Howard and a surrounding staff elite similar in its extra-parliamentary origins to Blair's joined the 'coalition of the willing' in Iraq despite intense parliamentary and public opposition. The Howard elite has twice launched risky military peacekeeping missions in East Timor, intervened with force in the Solomon Islands, threatened pre-emptive attacks on terrorist redoubts in Southeast Asia, and won three re-elections through bare-knuckled campaigns that whipped up voters' fears. In Italy for four years Silvio Berlusconi and the elite around him played fast and loose with parliamentary and judicial practices, exerted near monopoly control of television, and followed the Bush, Blair, and Howard elites into Iraq in the teeth of public opposition. In Denmark, where public anxieties about immigration have tended to override foreign affairs, Anders Fogh Rasmussen's government has cut the number of asylum seekers by half, paid Afghan asylum seekers to return home, and restricted the entry of Muslim clerics, without as yet stanching growth of the anti-immigrant People's Party and its demands for even more stringent measures. As illustrated by Donald Rumsfeld's six-year tenure at the Pentagon, top elite figures responsible for policy disasters cannot be controlled by parliaments or parties and can be ousted only by the paramount political leader.

Yet it must be asked if this onset of more leonine elites and forceful leaders is really just a blip on the radar screens of liberal democracies. Do we not mistake fairly normal alternations in power, perhaps made sharper by the magnitudes of today's centripetal pressures, for a basic and lasting change in elite and leader modes? There are many indications, after all, that the Bush elite has in its hubris and miscalculations disastrously over-extended US military power and destroyed the US claim to geo-political hegemony. Signs are numerous that the US political elite as a whole is deeply disillusioned by the course of events in Iraq and Afghanistan, by gross administrative incompetence when responding to Hurricane Katrina's devastation in 2005, and by corrupt and craven deals between Bush elite allies and sundry clienteles. If Democrats regain control of Congress in the November 2006 mid-term elections the elite's political paralysis will probably follow, and in any event Bush, Cheney and their top associates will exit power at the end of 2008. Extensive military repairs and yawning fiscal deficits will be crippling bills that their successors will then have to pay. The departure of Tony Blair and his entourage from power in London will precede the Bush elite's exit. Silvio Berlusconi is, for the moment at least, gone from power in Rome; Junichiro Koizumi vacates Japan's prime ministership in September 2006; Australia's 2007 federal election is certain to be John Howard's last. Although Anders Fogh Rasmussen's reelection in Denmark in 2005 was the first ever achieved by a Danish Liberal leader, his party, as well as the opposition Social Democrats, lost votes and seats to anti-immigrant and conservative competitors so that Rasmussen's political dominance is in doubt. And it remains to be seen if Stephen Harper and Angela Merkel and their executive elites can act forcefully 
in the absence of firm parliamentary control. As regards the jockeying of elites and leaders for presidential power in France, 'uncertain' and 'volatile' are unavoidable adjectives. In short, the patterns we have been exploring are ambiguous; they may be more ephemeral and putative than central and lasting. Nevertheless, they warrant a few concluding reflections.

\section{Conclusions}

For a start, today's seemingly more leonine elites and forceful leaders are quite timid when compared with forebears in interwar Europe. The shift that we have been exploring bears little substantive resemblance to the revolutionary changes that then took place. This difference is at least partly anticipated by Pareto's thesis that deep and violent elite circulations occur only as the result of wars or other truly explosive crises. Although it is conceivable that the Iraq and Afghanistan military quagmires may produce a major crisis in the U.S., the shift in elites and leaders there and everywhere else has to date occurred more or less gradually within each country's elite stratum and in conformance, by and large, with established institutions. There has been no clear rupturing of liberal democracy. But although timid by historical measure, the current elites and leaders we have discussed dress actions in nationalist and populist garbs and present themselves as champions of the morally upright 'heartland'. They portray terrorist threats to established ways of life as being so dire that harsh and peremptory actions, many of which cannot 'safely' be made public, are imperative. In a plebiscitary way they enlist mass support by daily and carefully orchestrated appearances in the mass media where they portray opponents as cowardly and unpatriotic.

Second, and as we said at the outset, the shift in elites and leaders is not uniform across the liberal democracies. Signs of it are fainter and more uneven in Europe than in the U.S., Australia, and, arguably, Japan, where Shinzo Abe, a hard-line nationalist who is an enthusiastic pilgrim to the Yasukuni Shrine, is tipped to succeed Koizumi as prime minister. But we should keep in mind that changes in interwar Europe were not uniform either, and they stretched over two decades. Mussolini and his fascists took power in 1922-24, Stalin did so in 1928-29, Hitler and the Nazis took over in 1933, the same year that Salazar instituted Portugal's Estado Novo; Dolfuss took control in Vienna a year later; Metaxas did so in Athens in 1936; Franco consolidated his regime only after the civil war in Spain. Meanwhile, France, the Low Countries, Scandinavia, and the Anglo-American democracies experienced no such basic interwar elite and leader change, although several, like Belgium, came perilously close to it. The current shift is, in other words, no more patchy - although it is certainly less clear-cut - than the interwar one.

Third, the extent to which the shift is a by-product of US developments nags our exploration. Because of US influence - 'hegemony' if one prefers - the Bush elite's aggressive actions promote comparable actions elsewhere. Thus governments led by Blair, Berlusconi, Howard, Rasmussen, and by José María Aznar in Spain joined the Bush elite's military interventions in Afghanistan and then Iraq, as did governing elites and leaders in most countries of Eastern Europe. They did this for reasons having as much to do with maintaining their alliances and trading relations with the all-important U.S. as with assessments that their own security interests dictated the costly interventions. Likewise, clampdowns on migrant communities that might be harbouring terrorist cells appear to be instigated, at least in part, by the demands of US intelligence agencies. It can be asked, in short, whether the shift we detect is mostly a reverberation of what has been occurring in the U.S. 
Another question, related to the one just posed, is whether the US developments - the Bush elite's ascendancy and actions - are themselves an aberration or fluke that will soon disappear. Despite a mountainous literature examining the Bush elite, there is no agreed understanding of it. In particular, the decision to attack Iraq continues to baffle those who have studied it from outside the elite's inner sanctum. The 9/11 terrorist attacks, which have been the main public rationale for the Iraq venture, did not change the international situation of the U.S. one iota. Like the air raid on Tokyo led by Jimmy Doolittle in early 1942, the 9/11 takeovers of passenger planes for use as guided missiles were almost certainly nonrepeatable, and, dramatic though they were, they exacted a cost in lives far fewer than the 17,000 homicides and 40,000 car accident fatalities each year in the U.S. While retaliating against al Queda and its Taliban hosts in Afghanistan was clearly warranted and politically essential, the decision to invade Iraq was either a blunder born of hubris and historic miscalculation about the ability of the U.S. to implant 'freedom and democracy' where it has never existed, or it was part of a much larger, though equally dubious, secret strategy to establish in Iraq a military platform from which the Middle East could be made safe for petroleum supplies and Israel. The consequence, in any event, has been an evisceration of the Bush elite's political credibility, even its legitimacy, so that it serves decreasingly as a beacon for elites and leaders in other liberal democracies. In this respect, a US stoking of the shift to more leonine elites and forceful leaders may be ending.

Strong centripetal pressures on liberal democracies remain, however, and they are likely to increase. Elites and leaders sense that these pressures require bolder and more forceful responses. With leaders who may be more ersatz than genuinely charismatic, liberal democracies will have still greater plebiscitary features. Appeals for support utilizing emotional and irrational rhetoric and the careful management of leader images are here to stay. Behind their trappings are likely to be more leonine elites that benefit politically from alliances with large and propertied plutocratic strata. What remains to be seen is how strong and vigorous these elites will be, how much they will value loyalty over expertise and intellectual advice, how sharply they will centralize executive power in a few hands, and, therefore, how prone they will be to errors, overstretching, and a new penetration by foxes. 


\section{References}

Antonio, Robert J. (1995), “Max Weber.” The Encyclopedia of Democracy, Congressional Quarterly Press.

Beetham, David (1985), Max Weber and the Theory of Modern Politics. Polity Press ( $2^{\text {nd }}$ edition).

Burch, Martin, and Ian Holliday (2004-2005), 'The Blair Government and the Core Executive.' Government and Opposition 39: 1-21.

Cannon, Lou (1982), President Reagan: The Role of a Lifetime. New York, Putnam.

Cotta, Maurizio (1992), 'Elite Unification and Democratic Consolidation in Italy: An Historical Overview." In J. Higley and R. Gunther, Elites and Democratic Consolidation in Southern Europe and Latin America, Cambridge Univ. Press, 146-77.

Femia, Joseph (2001), Against the Masses. Oxford Univ. Press.

Finer S.E. (1966) Vilfredo Pareto: Sociological Writings London: Pall Mall Press. (1968) 'Pareto and Pluto-Democracy: The Retreat to the Galapagos.' American Political Science Review 62: 440-450.

Field G. Lowell and John Higley (1980) Elitism. Routledge \& Kegan Paul.

Field, G. Lowell and John Higley (1986), 'After the Halcyon Years: Elites and Mass Publics at the Level of Full Development.' Jrnl. of Political \& Military Sociology, 14: 1 (Spring), 5-27.

Higley, John (2006) 'The Bush Elite: Aberration or Harbinger?' In B. O'Connor and M. Griffiths, eds., The Rise of Anti-Americanism. London, Routledge, 155-68.

Higley, John and Michael Burton (2006), Elite Foundations of Liberal Democracy. Rowman \& Littlefield.

Körösényi, András (2005), 'Political Representation in Leader Democracy,' Government and Opposition, 40 (3), 358-78.

Kristol, William and Robert Kagan (2000), Rebuilding America's Defenses: Strategy, Forces, and Resources for a New Century. Project for the New American Century.

Lind Michael (2003) Made in Texas: George W. Bush and the Southern Takeover of American Politics, Basic Books.

Macintyre, Stuart (2004), A Concise History of Australia. Cambridge Univ. Press.

Mann, James (2004), Rise of the Vulcans: The History of Bush's War Cabinet. Viking.

Linz, Juan (1978), Crisis, Breakdown \& Reequilibration. Johns Hopkins Univ. Press.

Linz, Juan and Alfred Stepan, eds. (1978) The Breakdown of Democratic Regimes: Europe. Johns Hopkins Univ. Press.

Lukacs, John (2005), Democracy and Populism: Fear and Hatred. Yale Univ. Press.

Pareto, Vilfredo (1935), The Mind and Society. Dover Publications.

(1921/1984), The Transformation of Democracy. English translation by Renata Girola, with an Introduction by Charles H. Powers, Transaction Publishers.

Parkin, Frank (1982), Max Weber. Tavistock Publications.

Parry G. (1969/2006) Political Elites. George Allen \& Unwin. Reprinted with a new Introduction, ECPR Monograph Series.

Paxton, Robert O. (2004), The Anatomy of Fascism. New York, Knopf.

Schmitter, Philippe C. (1974), 'Still the Century of Corporatism?' Review of Politics 36: 85-131.

Sica, Alan (1988), Weber, Irrationality, and Social Order. Univ. of California Press.

Suskind, Ron (2004), The Price of Loyalty: George W. Bush, the White House, and the Education of Paul $O$ 'Neill. Simon and Schuster.

Timasheff N.S (1965) 'The Social System, Structure and Dynamics.' In J.H.Meisel (ed.) Pareto and Mosca. Prentice-Hall, pp. 63-70.

Weber, Max (1978), Economy and Society. Univ. of California Press. 